\title{
Effect of Dispersoids on Tensile Deformation of Fe-20Cr ODS Alloys
}

\author{
Yozo KAWASAKI, Yuji IKEDA, Toshiharu KOBAYASHI and Hideshi SUMIYOSHI
}

National Research Institute for Metals, Sengen, Tsukuba, Ibaraki-ken, 305 Japan.

(Received on February 13, 1996; accepted in final form on July 15, 1996)

\begin{abstract}
Tensile deformation properties of nine kinds of mechanically alloyed Fe-20Cr-based oxide dispersion strengthened (ODS) steels were examined over a temperature range from 300 to $1073 \mathrm{~K}$. One of the specimens used was an alloy without any addition of oxide and the others were eight kinds of ODS alloys with the addition of $\mathrm{Y}_{2} \mathrm{O}_{3}, \mathrm{Al}_{2} \mathrm{O}_{3}, \mathrm{SiO}$ or $\mathrm{ZrO}_{2}$. All of the alloys had fine grain structures. With the addition of $\mathrm{Y}_{2} \mathrm{O}_{3}$ the $0.2 \%$ yield stress of $\mathrm{Fe}-20 \mathrm{Cr}$ alloys increased all over the temperature range, and the work-hardening following the yield at 300 and $673 \mathrm{~K}$ also increased considerably. But at higher temperatures than $673 \mathrm{~K}$, the increment of work hardening due to the oxide dispersion was small. Fracture elongation at $673 \mathrm{~K}$ was found to be about $5 \%$, while those at 873 and $1073 \mathrm{~K}$ were more than $17 \%$. The dispersion strengthening due to the other oxides, $\mathrm{Al}_{2} \mathrm{O}_{3}, \mathrm{SiO}$ and $\mathrm{ZrO}_{2}$ were very small except that of $\mathrm{ZrO}_{2}$ at $1073 \mathrm{~K}$.
\end{abstract}

KEY WORDS: $\mathrm{Fe}-20 \mathrm{Cr}$ ODS alloys; $\mathrm{Y}_{2} \mathrm{O}_{3} ; \mathrm{Al}_{2} \mathrm{O}_{3} ; \mathrm{SiO}$ and $\mathrm{ZrO}_{2}$ oxides; tensile deformation properties.

\section{Introduction}

One of authors found that the addition of rare earth metals (REM) into austenitic steels and $\mathrm{Y}_{2} \mathrm{O}_{3}$ into superalloys caused trapping of sulfur atoms at the interfaces between matrices and oxide particles, and that these trapping suppressed the segregation of sulfur on the specimen surface and in consequence suppressed the spalling of $\mathrm{Al}_{2} \mathrm{O}_{3}$ coating layer. ${ }^{2}$ In the previous work, ${ }^{2)}$ the effect of REM and $\mathrm{Y}_{2} \mathrm{O}_{3}$ addition on the materials properties was examined in mechanically alloyed (MA) $\mathrm{Fe}-20 \mathrm{Cr}$ ODS ferritic steels, and it was found that, in contrast with austenitic steels and superalloys, rapid segregation of sulfur occurred on the surfaces of ODS ferritic alloys but the spalling of $\mathrm{Al}_{2} \mathrm{O}_{3}$ coating films being little. This result shows one of the excellent characteristics of ferritic MA ODS.

The MA 956 ferritic steel with the composition of $\mathrm{Fe}-20 \mathrm{Cr}-4.5 \mathrm{Al}-0.5 \mathrm{Ti}-0.5 \mathrm{Y}_{2} \mathrm{O}_{3}$, has various interesting properties, particularly the excellent resistance against oxidation and hot corrosion, and hence is used for combustion chamber. ${ }^{3)}$ The tensile strength of this steel at high temperatures, $1385 \mathrm{~K}$ for example, increases with increasing strain rate, while the ductility in low strain rates is small. ${ }^{4)}$ The ODS ferritic steel is also promising for the fuel cladding of FBR (Fast Breeder Reactor) in Japan, because of their good resistance to swelling and of excellent strength at elevated temperatures. Okuda et al. found that $\mathrm{Fe}-13 \mathrm{Cr} \mathrm{MA}$ ODS $\left(\mathrm{Y}_{2} \mathrm{O}_{3}\right)$ ferritic steel was strengthened further by adding Titanium and Molybdenum and that swelling was suppressed by adding Titanium. ${ }^{5)}$

The excellent properties of MA 956 and $\mathrm{Fe}-13 \mathrm{Cr} \mathrm{MA}$ ODS have been found to connect closely with the dispersion of $\mathrm{Y}_{2} \mathrm{O}_{3}$ fine particles. However, the roles of other oxide particles on the materials properties of ferritic MA ODS have not been systematically investigated yet. This work is aimed to study the effects of various dispersoids on the tensile properties of $\mathrm{Fe}-20 \mathrm{Cr}$-based ODS alloys. For this purpose the same mechanically alloyed specimens as those prepared for the previous work $^{2)}$ were used; an $\mathrm{Fe}-20 \mathrm{Cr}$ steel without addition of oxide and eight kinds of $\mathrm{Fe}-20 \mathrm{Cr}$-based ODS alloys containing $\mathrm{Y}_{2} \mathrm{O}_{3}, \mathrm{Al}_{2} \mathrm{O}_{3}, \mathrm{SiO}$ or $\mathrm{ZrO}_{2}$. Those are listed in Table 1.

\section{Experimental Procedure}

The chemical compositions of the nine kinds of $\mathrm{Fe}-20 \mathrm{Cr}$-based alloys are shown in Table 1, where the symbol $\mathrm{FC}-00$ means $\mathrm{Fe}-20 \mathrm{Cr}$ alloy without addition of oxide, and $\mathrm{FC}-3 \mathrm{Y}$ for example, is the alloy with addition of nominal $0.3 \% \mathrm{Y}_{2} \mathrm{O}_{3}$; FC-YA is the alloy only to which two kinds of oxides, nominal $0.5 \% \quad \mathrm{Y}_{2} \mathrm{O}_{3}$ and $0.3 \% \mathrm{Al}_{2} \mathrm{O}_{3}$ are added. The amount of each oxide was calculated from the analytically determined amount of metal element making oxide, and the residual amount of oxygen, $\operatorname{re}(\mathrm{O})$, is the rest value in subtracting the amount of oxygen in the form of oxides from the analytical total amount of oxygen, an $(\mathrm{O})$. Table 1 shows that the amount of residual oxygen in the alloys containing $\mathrm{Y}_{2} \mathrm{O}_{3}$ is much higher than that in FC-00 alloy, and is much lower in the other alloys. $\mathrm{Y}_{2} \mathrm{O}_{3}$ in $\mathrm{FC}-\mathrm{YA}$ alloy may form some complex oxides like $3 \mathrm{Y}_{2} \mathrm{O}_{3}-5 \mathrm{Al}_{2} \mathrm{O}_{3}{ }^{6)}$ and also complex oxides of $\mathrm{Fe}$ and/or $\mathrm{Cr}$ may be formed in $\mathrm{FC}-00$ alloy with $0.34 \% \mathrm{O}$ and strengthen it. However, complex oxides were not taken into account for the calculation of the amount of oxides given in Table 1 .

The alloys were manufactured by INCO Ltd. Raw powder of the constituent elements for each alloy was 
Table 1. Analytical chemical compositions of Fe-20Cr ODS alloys. (mass\%)

\begin{tabular}{|c|c|c|c|c|c|c|c|c|}
\hline Alloy & $\mathrm{Cr}$ & $\mathrm{Y}\left(\mathrm{Y}_{2} \mathrm{O}_{3}\right)$ & $\operatorname{Al}\left(\mathrm{Al}_{2} \mathrm{O}_{3}\right)$ & $\mathrm{Si}(\mathrm{SiO})$ & $\mathrm{Zr}\left(\mathrm{ZrO}_{2}\right)$ & $\operatorname{an}(O)$ & $\mathrm{re}(\mathrm{O})^{*}$ & vol $\%$ of oxide \\
\hline $\mathrm{FC}-00$ & 19.08 & & & & & 0.34 & 0.34 & \\
\hline $\mathrm{FC}-3 \mathrm{Y}$ & 19.21 & $0.23(0.29)$ & & & & 0.61 & 0.55 & 0.7 \\
\hline FC-5Y & 19.31 & $0.30(0.38)$ & & & & 0.67 & 0.59 & 1.0 \\
\hline $\mathrm{FC}-8 \mathrm{Y}$ & 18.91 & $0.45(0.63)$ & & & & 0.79 & 0.61 & 1.6 \\
\hline $\mathrm{FC}-11 \mathrm{Y}$ & 18.94 & $0.77(0.98)$ & & & & 0.74 & 0.53 & 2.5 \\
\hline$F C-Y A$ & 19.12 & $0.55(0.70)$ & $0.16(0.30)$ & & & 0.78 & 0.49 & 2.6 \\
\hline $\mathrm{FC}-5 \mathrm{~A}$ & 18.95 & & $0.28(0.53)$ & & & 0.40 & 0.15 & 1.0 \\
\hline EC-6S & 20.70 & & & $0.40(0.63)$ & & 0.51 & 0.29 & 3.2 \\
\hline $\mathrm{FC}-12 \mathrm{Z}$ & 19.28 & & & & $0.57(0.77)$ & 0.52 & 0.32 & 1.7 \\
\hline
\end{tabular}

Impurity; $\mathrm{Cu} ; 0.03 / \mathrm{Mn} ; 0.07 / \mathrm{P} ; 0.003 / \mathrm{S} ; 0.006 / \mathrm{C}: 0.04 / \mathrm{N} ; 0.30$.

$* \operatorname{re}(\mathrm{O})=\operatorname{an}(\mathrm{O})-\operatorname{oxide}(\mathrm{O})$.

Table 2. Grain sizes of $\mathrm{Fe}-20 \mathrm{Cr}$ ODS alloys.

\begin{tabular}{lccc}
\hline Alloy & $\begin{array}{c}\text { Cross sec. } \\
\mu \mathrm{m} \text { (st. dev.) }\end{array}$ & $\begin{array}{c}\text { Longi. sec. } \\
\mu \mathrm{m} \text { (st. dev.) }\end{array}$ & $\begin{array}{c}\text { Grain aspect } \\
\text { ratio; } d_{1} / d_{\mathrm{c}}\end{array}$ \\
\hline FC-00 & $4.3(0.4)$ & $5.6(0.4)$ & 1.3 \\
FC-3Y & $5.1(0.9)$ & $6.4(0.6)$ & 1.25 \\
FC-5Y & $4.4(0.3)$ & $6.6(0.7)$ & 1.5 \\
FC-8Y & $4.1(0.3)$ & $8.1(0.9)$ & 1.97 \\
FC-11Y & $4.4(0.4)$ & $5.7(0.4)$ & 1.3 \\
FC-YA* & $4.0(0.7)$ & - & 1.05 \\
FC-5A & $8.7(0.8)$ & $9.2(0.8)$ & 1.21 \\
FC-6S & $10.3(1.0)$ & $12.5(1.0)$ & \\
FC-12Z* & $3.8(0.8)$ & - & \\
\hline
\end{tabular}

* TEM photographs.

mechanically alloyed by an attritor for $86.4 \mathrm{ks}(24 \mathrm{~h})$, put in an evacuated iron can and extruded at $1338 \mathrm{~K}$ in a form of plate included iron sheath with $50 \mathrm{~mm}$ width and $13 \mathrm{~mm}$ thickness. The plate was first heat treated at $1473 \mathrm{~K}$ for $7.2 \mathrm{ks}(2 \mathrm{~h})$ in Ar atmosphere. The specimens for tensile test were made by cutting from the plate parallel to extrusion direction followed by shaping with an NC turning lathe. Each specimen had a shape of $50 \mathrm{~mm}$ total length, with $8 \mathrm{~mm}$ phi thick screws on both tops to pull, $4 \mathrm{~mm}$ phi $\times 16 \mathrm{~mm}$ gauge length part, and $5 \mathrm{~mm}$ radius shoulder parts. The specimens were polished finally with emery papers of $\$ 2000$, and heat-treated again at $1473 \mathrm{~K}$ for $7.2 \mathrm{ks}(2 \mathrm{~h})$ in $\mathrm{Ar}$ atmosphere.

Tensile tests were carried out at $300,673,873$ and $1073 \mathrm{~K}$ with a strain rate $5 \times 10^{-3} \mathrm{~s}^{-1}$. The temperature $1073 \mathrm{~K}$ corresponds to $60 \%$ the melting point $1786 \mathrm{~K}$ of $\mathrm{Fe}-20 \mathrm{Cr}$ alloy. Formation of fiber textures in the alloys due to the extrusion was examined with an X-ray diffractometer (Rigaku-RAD-IIB), while the crystalline microstructures were observed with optical microscopy after etching the alloys at $300 \mathrm{~K}$ in a solution of $30 \mathrm{~g}$ $\mathrm{NH}_{4} \mathrm{~F}, 50 \mathrm{cc} \mathrm{HNO}_{3}$ and $20 \mathrm{cc}$ water. Distribution of oxide particles and dislocation structures were observed with transmission electron microscopy (TEM) employing JEOL-2000; thin plates were cut perpendicular to the tensile direction from fractured specimens, and thinned electrolytically at $260 \mathrm{~K}$ in an etchant solution of ethanol and $10 \%$ perchloric acid.

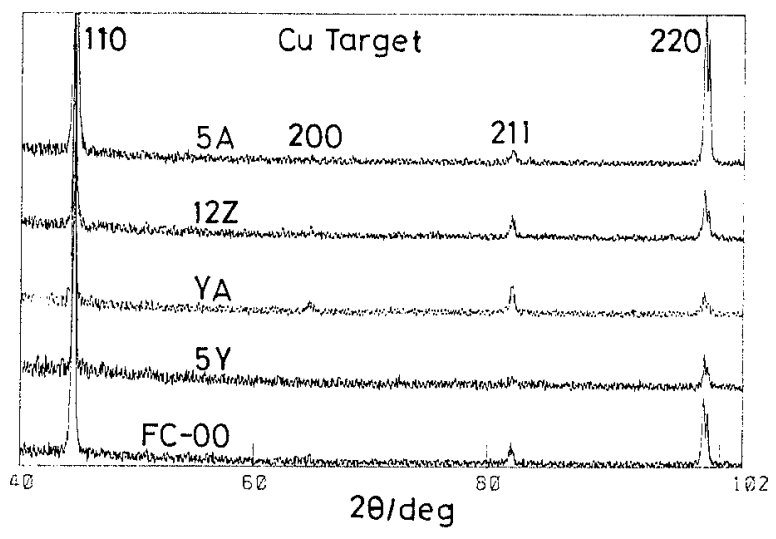

Fig. 1. X-ray diffraction patterns of the transversal section plane of various alloys.
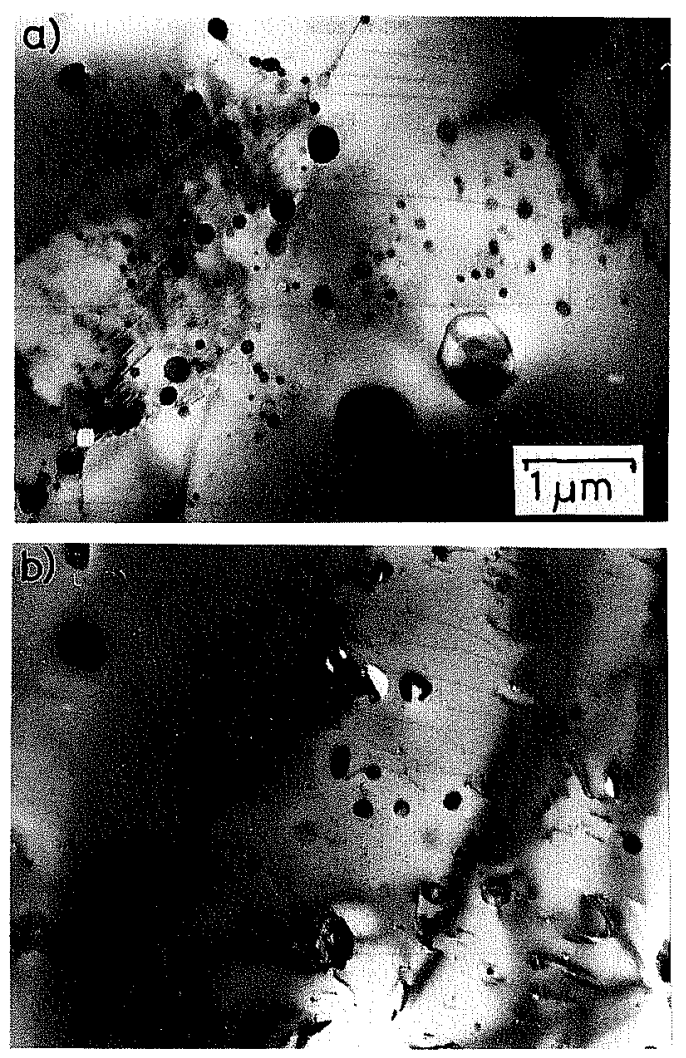

Fig. 2. TEM microstructures of $\mathrm{FC}-\mathrm{I} 1 \mathrm{Y}$ and $-5 \mathrm{~A}$ alloys. 


\section{Results and Discussion}

\subsection{Microstructures}

Table 2 shows the averaged grain sizes that were measured lengthwise and breadthwise from those optical micrographs, as shown in Fig. 4, which were taken on the longitudinal side sections of fractured specimens. The grain sizes of FC-YA and $-12 Z$ alloy specimens, however, were estimated from their TEM photographs because it was difficult to etch either chemically or by ion-sputtering. ${ }^{7)}$ The grain sizes of both $\mathrm{FC}-00$ and $\mathrm{Y}_{2} \mathrm{O}_{3}$ containing alloys were 4-5 micron meters and those of

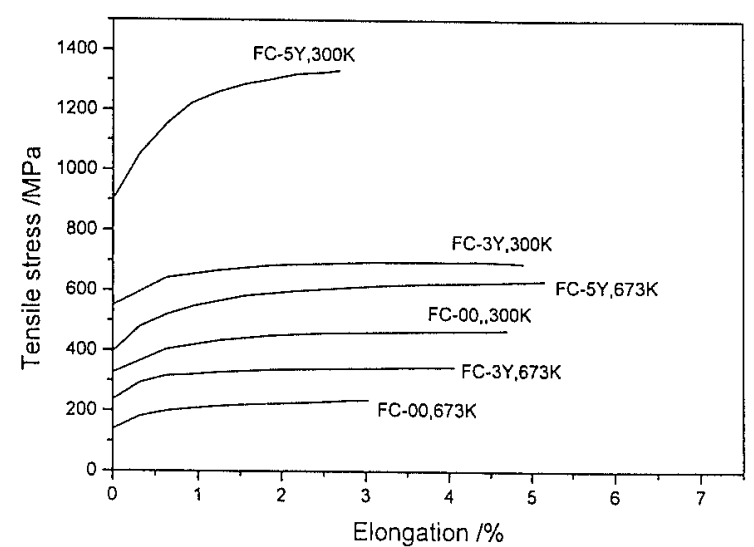

(a)

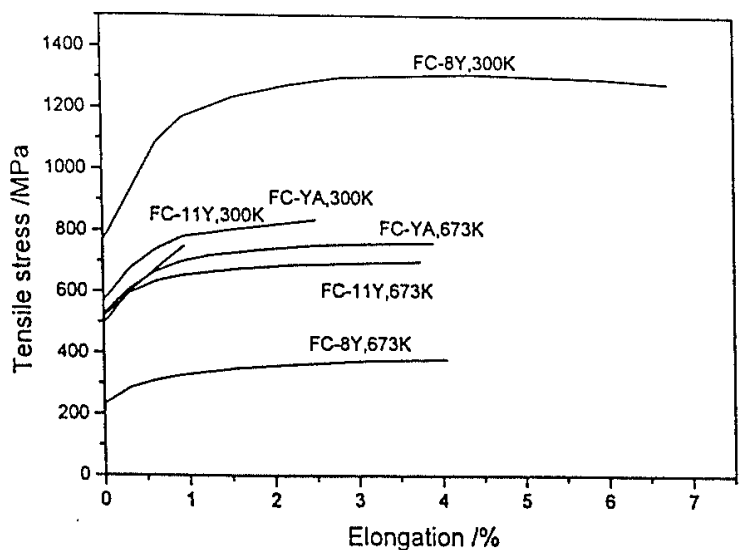

(c)

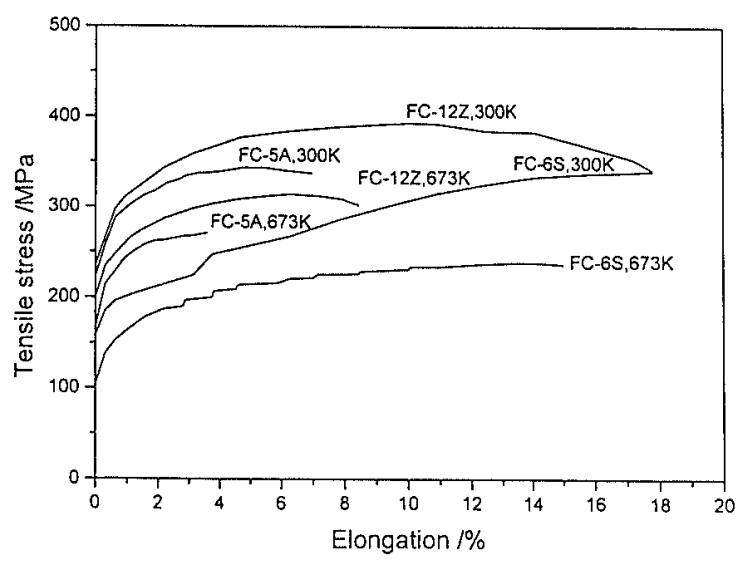

(e) both $\mathrm{FC}-5 \mathrm{~A}$ and $-6 \mathrm{~S}$ alloys were 8-10 micron meters. The aspect ratio of grain was at most only 2; this might be caused by the reason that the extrusion was carried out at a temperature range that recrystallization did not occur.

X-ray diffraction patterns for the transversal crosssections of the specimens are shown in Fig. 1. The highest and next highest peaks were 110 and 220 , respectively, having the ratio of about $1: 0.12$, and other 200 and 211 peaks were very low. This shows that all of the textures in the nine alloys have strong preferred orientation for 110 .

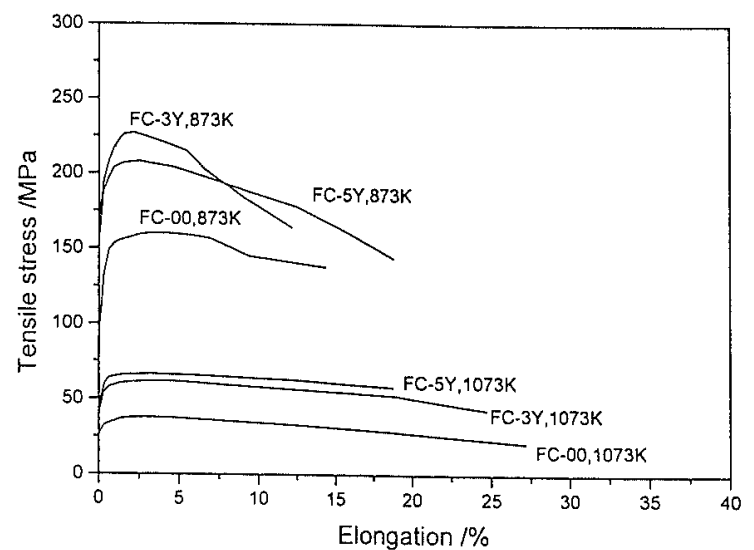

(b)

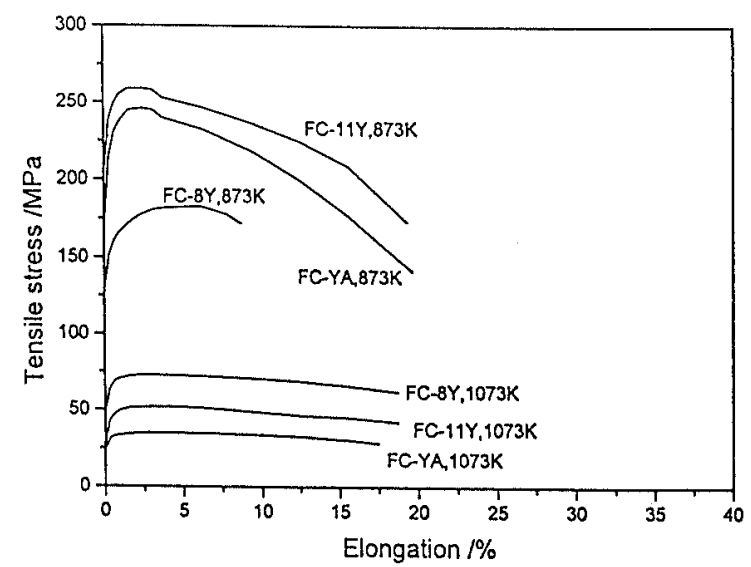

(d)

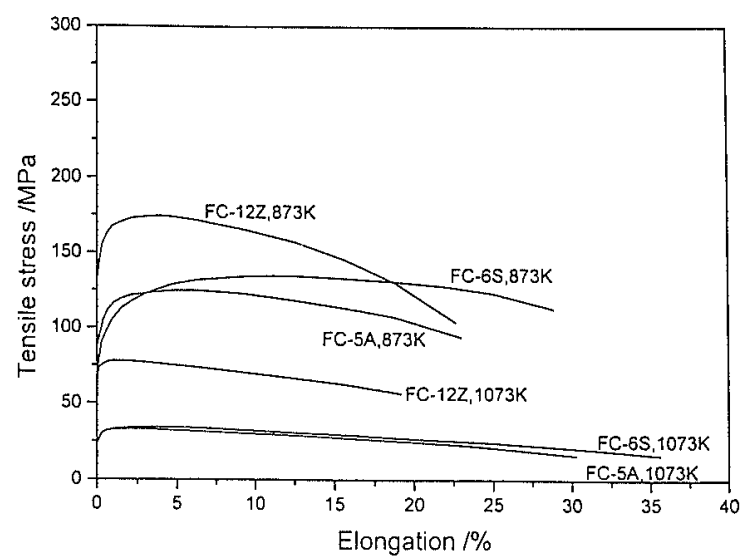

(f)

Fig. 3. Tensile stress ws. elongation curves, (a) FC-00, $-3 \mathrm{Y}$ and $-5 \mathrm{Y}$ alloys at 300 and $673 \mathrm{~K}$ (b) at 873 and $1073 \mathrm{~K}$, (c) FC-8Y, $-11 \mathrm{Y}$ and $-\mathrm{YA}$ alloys at 300 and $673 \mathrm{~K}$, (d) at 873 and $1073 \mathrm{~K}$, (e) FC-5A, $-6 \mathrm{~S}$ and $-12 \mathrm{Z}$ alloys at 300 and $673 \mathrm{~K}$, (f) at 873 and $1073 \mathrm{~K}$. 

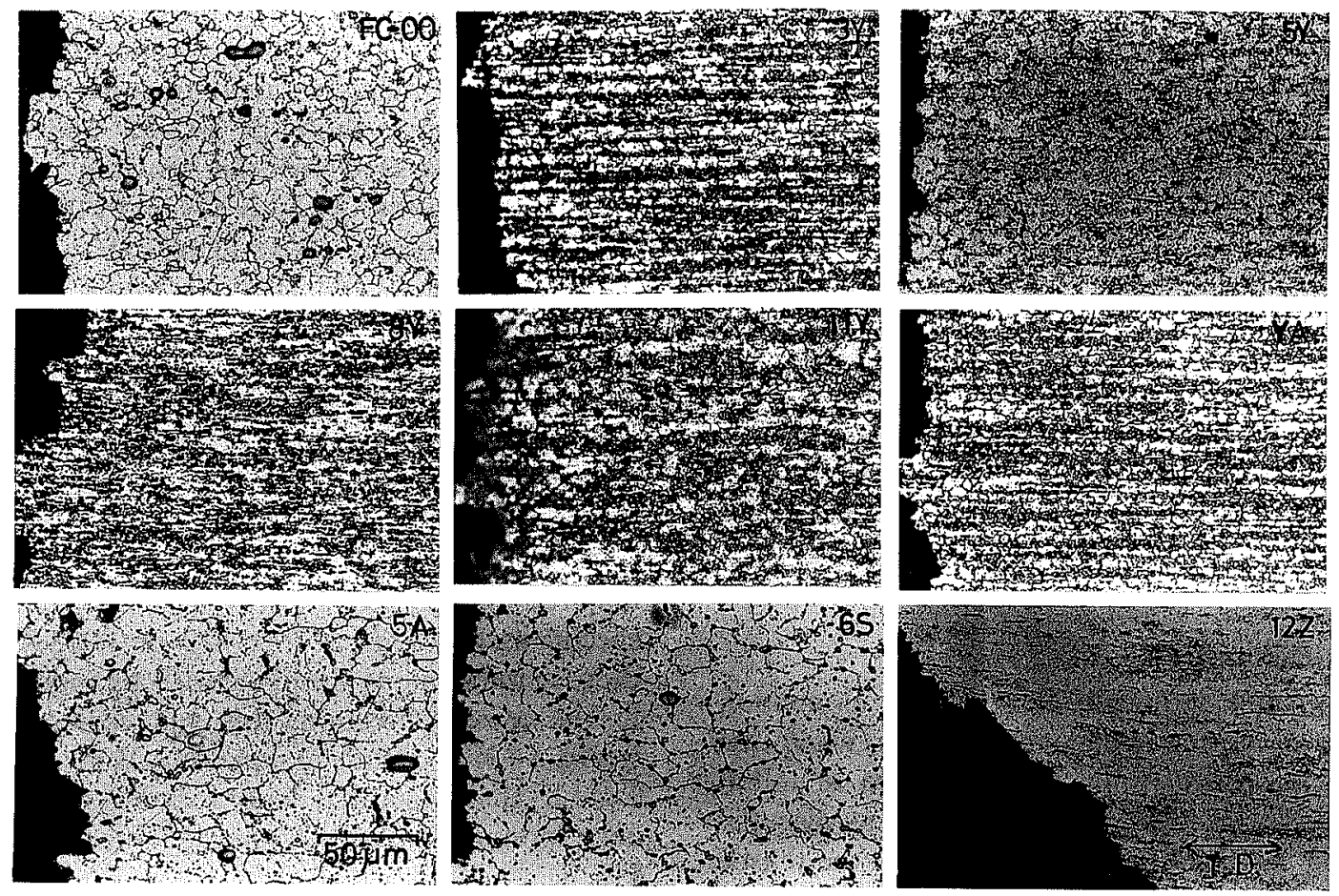

Fig. 4. Optical microstructures of the longitudinal side section of various alloy specimens fractured at $300 \mathrm{~K}$
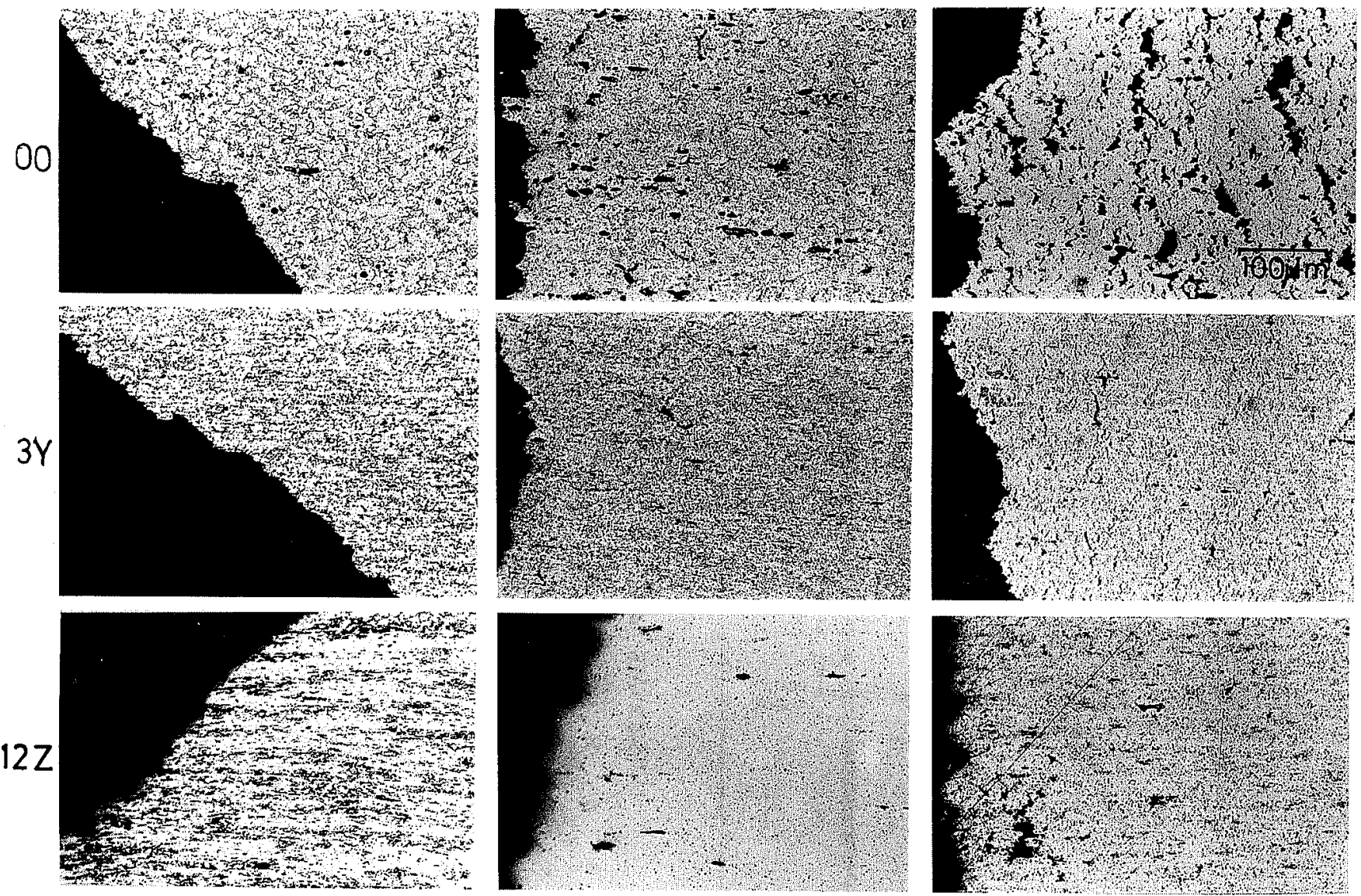

$673 \mathrm{~K}$

$873 K$

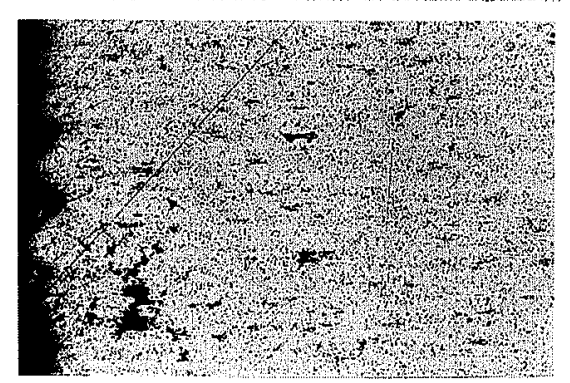

1073K

Fig. 5. Optical microstructures of the longitudinal side section of specimens, FC $-00,-3 \mathrm{Y}$ and $-12 \mathrm{Z}$ alloys, fractured at 673,873 or $1073 \mathrm{~K}$. 
Microstructural distribution of dispersoids in FC-11 Y and $-5 \mathrm{~A}$ alloys are shown in Figs. 2(a) and 2(b), where the mean radii of $\mathrm{Y}_{2} \mathrm{O}_{3}$ and $\mathrm{Al}_{2} \mathrm{O}_{3}$ are 50 and $95 \mathrm{~nm}$, respectively. The radius of $\mathrm{Y}_{2} \mathrm{O}_{3}$ in other alloys containing $\mathrm{Y}_{2} \mathrm{O}_{3}$ agreed roughly with that shown in Figs. 2(a). The radius of $\mathrm{SiO}$ in $\mathrm{FC}-6 \mathrm{~S}$ alloy was about $93 \mathrm{~nm}$, being similar with that of $\mathrm{Al}_{2} \mathrm{O}_{3}$ in Fig. 2(b). The radius of $\mathrm{ZrO}_{2}$ in $\mathrm{FC}-12 \mathrm{Z}$ alloy was approximately $40 \mathrm{~nm}$. The volume fraction in percentage of $\mathrm{Y}_{2} \mathrm{O}_{3}$ in $\mathrm{FC}-11 \mathrm{Y}$ alloy was 2.5 and the average spacing between the oxide particles was about 5 times as large as the average radius. In all of the eight alloys with oxide particles, the dispersion of the particles was found to be non-uniform, as shown in Figs. 2(a) and 2(b) for the two alloys. This may show the shortage of time even in the mechanical alloying for $86.4 \mathrm{ks}(24 \mathrm{~h})$ by the attritor.

\subsection{Tensile Deformation}

Figures 3(a)-3(f) show tensile stress $v s$. elongation curves of the alloys at various temperatures, where the tensile stress is defined as the load per area of initial cross-section and the elongation is defined as also the length per the initial gauge-length. At $300 \mathrm{~K}$ the tensile stresses of $\mathrm{FC}-00,-5 \mathrm{Y},-11 \mathrm{Y},-\mathrm{YA}$ and $-6 \mathrm{~S}$ alloys increased monotonously with the increase in elongation until fracture, while those of the other alloys decreased in large elongation and then fractured. The fracture elongation of $\mathrm{FC}-11 \mathrm{Y}$ alloy was relatively small; this

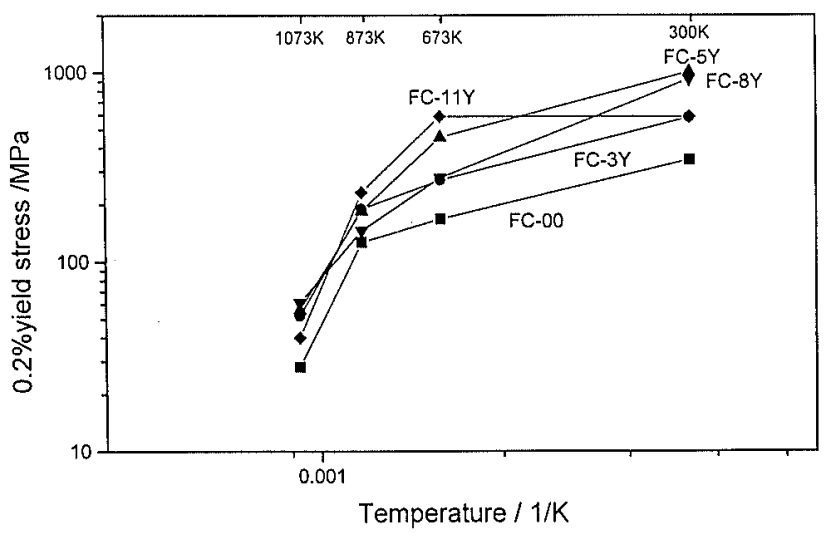

(a)

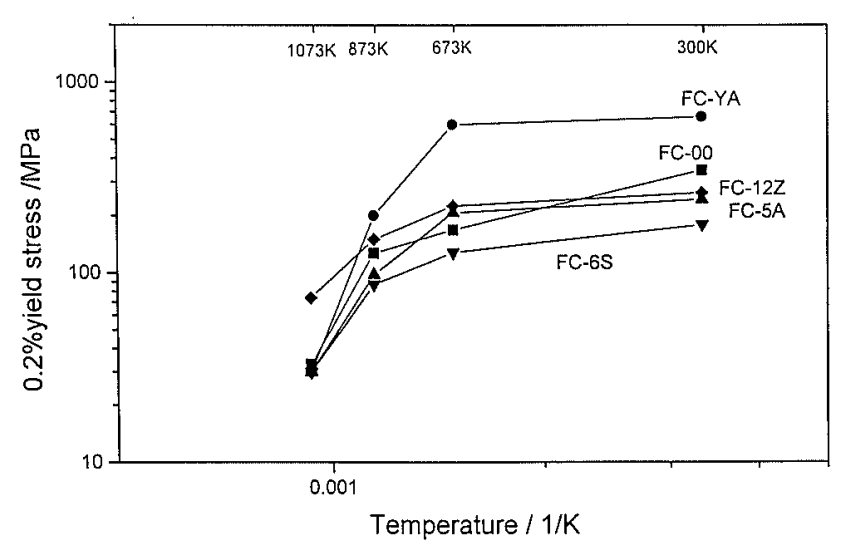

(b)

Fig. 6. $0.2 \%$ yield stress $w$. inverse of temperature (K), (a) FC- $-00,-3 \mathrm{Y},-5 \mathrm{Y},-8 \mathrm{Y}$ and $-11 \mathrm{Y}$ alloys, (b) FC-00, $-\mathrm{YA},-5 \mathrm{~A},-6 \mathrm{~S}$ and $-12 \mathrm{Z}$ alloys. was confirmed by repeating the tensile test. At $673 \mathrm{~K}$ the tensile stresses of alloys except FC-6S and $-12 Z$ monotonously increased until fracture with increasing elongation, while those of $\mathrm{FC}-6 \mathrm{~S}$ and $-12 \mathrm{Z}$ alloys decreased in large elongation showing relatively large fracture elongation. At both 873 and $1073 \mathrm{~K}$ the tensile stresses in all of the alloys increased at the beginning, reached maxima, and then decreased until fracture, showing large fracture elongation.

Figures 4(a)-4(f) show the optical micrographs of longitudinal-side section of various alloy specimens fractured at $300 \mathrm{~K}$. At this temperature, all of the specimens except for FC-12Z showed transgranular fracture perpendicular to the tensile direction with small elongation. Figure 5 shows the photographs of longitudinal-side section of $\mathrm{FC}-00,-3 \mathrm{Y}$ and $-12 \mathrm{Z}$ alloy specimens fractured at 673,873 or $1073 \mathrm{~K}$. At $673 \mathrm{~K}$, they fractured along the plane with an angle of 45 degree to the tensile direction; this will corresponds to the fracture with small elongation. While at 873 and $1073 \mathrm{~K}$ they fractured with forming cups and cones, corresponding to large fracture elongation as shown in Fig. 8.

Figures 6(a) and $\mathbf{6 ( b )}$ show $0.2 \%$ yield stresses $v s$.

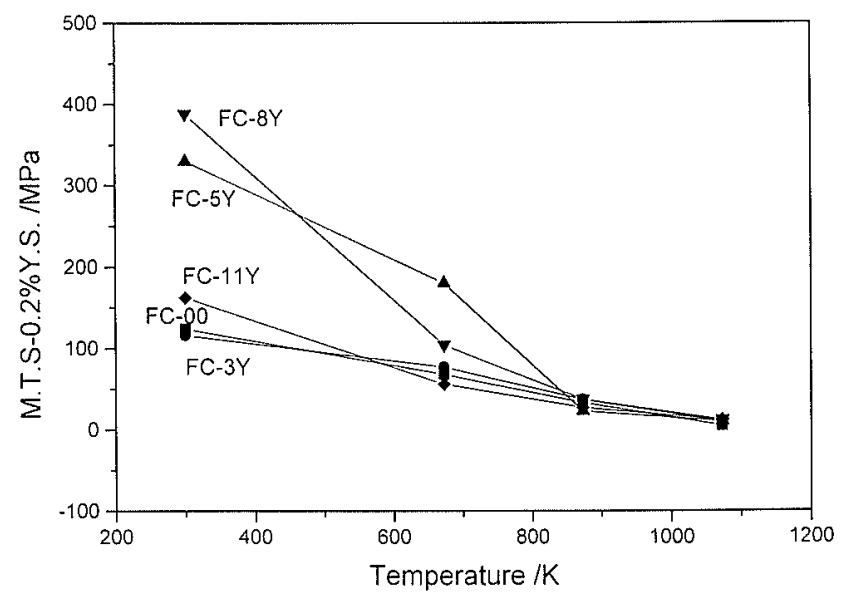

(a)

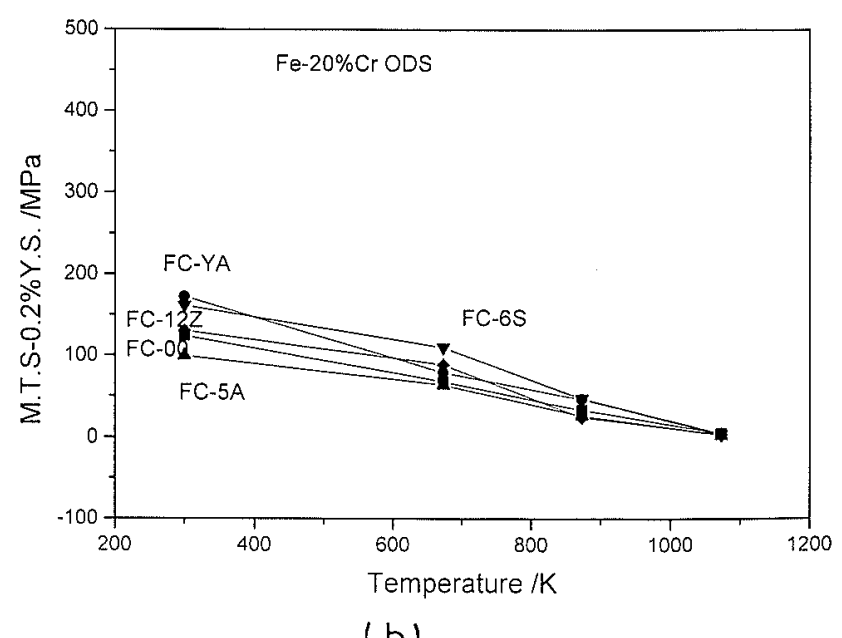

(b)

Fig. 7. Difference between maximal tensile stress and $0.2 \%$ yield stress ws. temperature, (a) FC $-00,-3 \mathrm{Y},-5 \mathrm{Y},-8 \mathrm{Y}$ and $-11 \mathrm{Y}$ alloys, (b) FC $-00,-\mathrm{YA},-5 \mathrm{~A},-6 \mathrm{~S}$ and $-12 \mathrm{Z}$ alloys. 
inverse of temperature $(\mathrm{K}) . \mathrm{Y}_{2} \mathrm{O}_{3}$ containing alloys were stronger than $\mathrm{FC}-00$ over the temperature range. The increase of $0.2 \%$ yield stresses, however, was not proportional to $\mathrm{Y}_{2} \mathrm{O}_{3}$ content, presumably because of non-uniform dispersion of $\mathrm{Y}_{2} \mathrm{O}_{3}$ particles. Other oxide particles, in contrast with $\mathrm{Y}_{2} \mathrm{O}_{3}$, did not strengthen $\mathrm{FC}-20 \mathrm{Cr}$ alloy over the temperature range except $\mathrm{ZrO}_{2}$ at $1073 \mathrm{~K}$, but $0.2 \%$ yield stress of $\mathrm{FC}-00$ at $300 \mathrm{~K}$ was even a little higher than those of FC-5A, $-6 \mathrm{~S}$ and $-12 \mathrm{Z}$. This is probably because that high residual oxygen content in FC-00 alloy strengthen itself, by forming some kind of oxide particle. At about $1073 \mathrm{~K}$, each stress-elongation curves showed a steep slope at the $0.2 \%$ yield stress. However, the role of oxide particles on the slope is little effective, because the curve for FC-00 alloy also showed a similar steep slope; instead, it is supposedly attributable to vacancy defects which take important part in the deformation at so high temperature as $1073 \mathrm{~K}$. If this is true, the gradient of the slope have a relation with the inverse of temperature in thermal activation process.

Figures 7 (a) and $\mathbf{7 ( b )}$ show the difference between maximal tensile stress and $0.2 \%$ yield stress $v s$. temperature; this difference is a measure for workhardening. The values of the difference at $300 \mathrm{~K}$ for FC-5Y and $-8 \mathrm{Y}$ alloys were about $300 \mathrm{MPa}$ and much larger than the value $120 \mathrm{MPa}$ for $\mathrm{FC}-00$ alloy. This fact shows that $\mathrm{Y}_{2} \mathrm{O}_{3}$ particles play an important role in

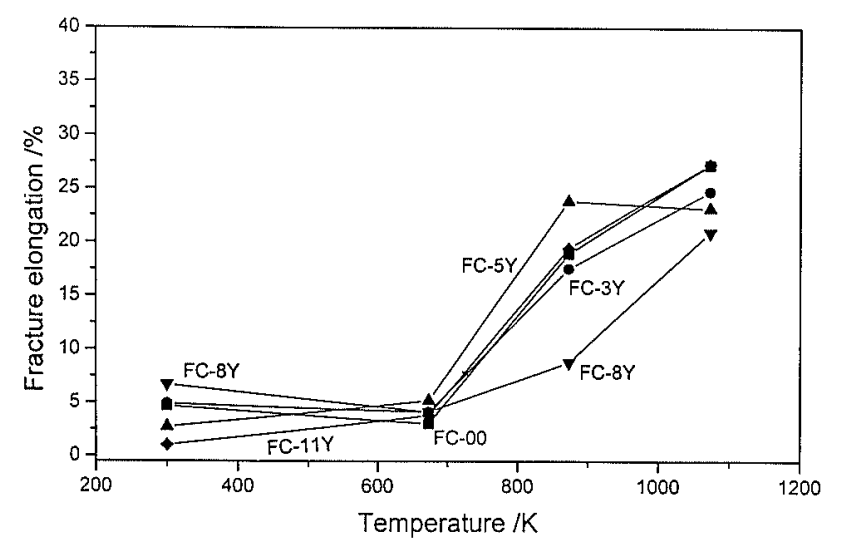

(a)

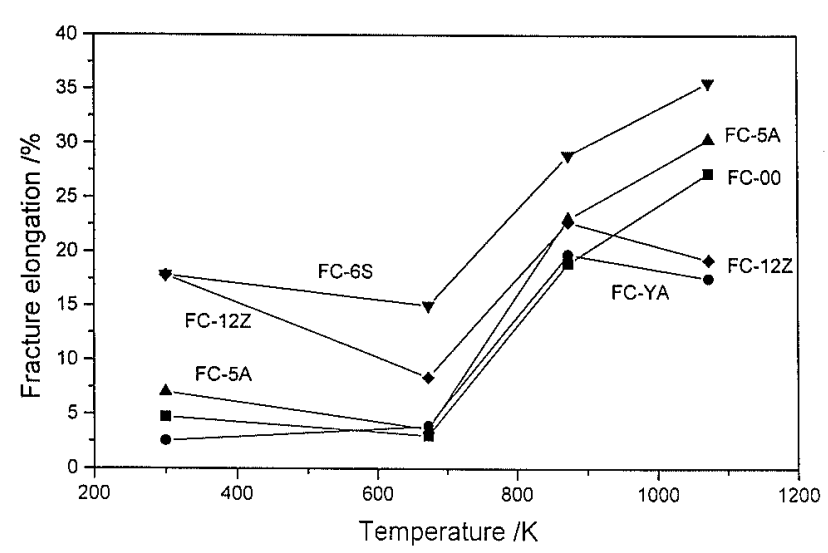

(b)

Fig. 8. Fracture elongation at various temperatures, (a) FC- $-00,-3 \mathrm{Y},-5 \mathrm{Y},-8 \mathrm{Y}$ and $-11 \mathrm{Y}$ alloys, (b) FC-00, $-\mathrm{YA},-5 \mathrm{~A}, 6 \mathrm{~S}$ and $-12 \mathrm{Z}$ alloys. work-hardening.

Figures 8(a) and 8(b) show the fracture elongation of the alloys at various temperatures. The curves for the alloys except FC-5Y, $-11 \mathrm{Y}$ and -YA seem to have minima around $673 \mathrm{~K}$, and these minima accorded to the fracture along the planes with an angle of 45 degree to the tensile direction. This fracture with minimal elongation seems to be due to the so-called $748 \mathrm{~K}\left(475^{\circ} \mathrm{C}\right)$ brittleness of $\mathrm{FC}-20 \mathrm{Cr}$ alloy at $748 \mathrm{~K}$, causing from spinodal decomposition. In passing, Read and Mura$\mathrm{kami}^{8)}$ have recently investigated on aging behavior of MA 956 using APFIM technique, and found that $\mathrm{Cr}$ concentration fluctuation took place on a microscopical scale of $10 \mathrm{~nm}$ in accompany with the increase of the hardness of the alloy.

Figure 9 shows TEM microstructures of alloy fractured at various temperatures. In Fig. 9(a), very dense dislocations along complex slip lines were observed and corresponded to the high strength of FC-3Y. At $300 \mathrm{~K}$, highly dense dislocations were also formed in the other alloys. At $673 \mathrm{~K}$, in Fig. 9(b), dislocation arrangements with high density were formed while substructures were not observed. At 873, in Fig. 9(c), indistinct dislocation substructures were formed and the average size was about 0.3 micrometer. At $1073 \mathrm{~K}$, in Fig. 9(d), the substructures were clearly formed and the average size was 0.9 micrometer. The temperature dependence of dislocation arrangements in all of the alloys examined was similar with what shown in Figs. 9(a)-9(d), though the figures are for various alloys.

\section{Conclusions}

Tensile properties of $\mathrm{Fe}-20 \mathrm{Cr}$ alloy and $\mathrm{Fe}-20 \mathrm{Cr}$ based oxide dispersion alloys with $\mathrm{Y}_{2} \mathrm{O}_{3}, \mathrm{Al}_{2} \mathrm{O}_{3}, \mathrm{SiO}$ or $\mathrm{ZrO}_{2}$ oxides were examined over a temperature range from 300 to $1073 \mathrm{~K}$. The alloys were manufactured by the method of mechanical alloying. Following results were obtained with respect to the effects of oxide dispersoids on tensile properties of the alloys.

(1) $0.2 \%$ yield stress of $\mathrm{Fe}-20 \mathrm{Cr}$-based alloys is enhanced by $\mathrm{Y}_{2} \mathrm{O}_{3}$ particles over the testing temperature range. The enhancement due to the particles at high temperatures is small, presumably because the effect of original fine grain size prevails.

(2) $\mathrm{Y}_{2} \mathrm{O}_{3}$ particles cause the large work-hardening of the $\mathrm{Fe}-20 \mathrm{Cr}$-based alloys at $300 \mathrm{~K}$.

(3) Fracture elongations of the alloys except FC-6S and $-12 \mathrm{Z}$, at 300 and $673 \mathrm{~K}$ are about $5 \%$, and seem to show minima at about $673 \mathrm{~K}$. The fracture elongations of the alloys except FC-8Y, at 873 and $1073 \mathrm{~K}$ are larger than $17 \%$.

(4) Strengthening effect of $\mathrm{Al}_{2} \mathrm{O}_{3}, \mathrm{SiO}$ and $\mathrm{ZrO}_{2}$ oxide particles on the $\mathrm{Fe}-20 \mathrm{Cr}$-based alloys is generally little, except that of $\mathrm{ZrO}_{2}$ at $1073 \mathrm{~K}$.

\section{Acknowledgments}

The authors are very thankful to Dr. S. Yamamoto for setting up $\mathrm{NC}$ lathe several times, and to $\mathrm{Mr}$. $\mathrm{H}$. Tanaka for etching the alloy specimens by ion sputtering. They are also indebted to Dr. K. Yagisawa for his valuable discussion on the manuscript. 

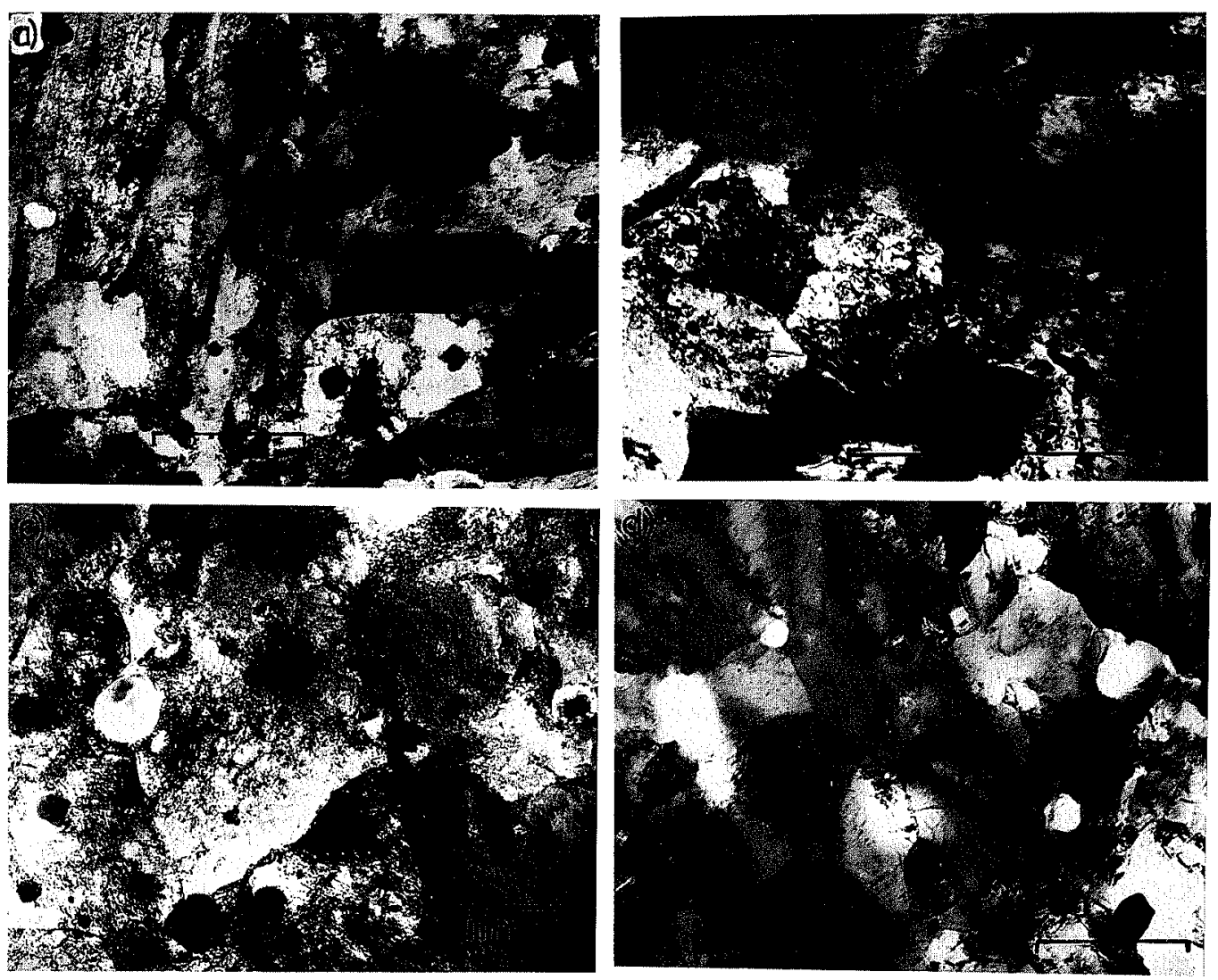

Fig. 9. TEM microstructures in the transversal cross section of fractured specimens, (a) FC-3Y alloy at $300 \mathrm{~K}$, (b) FC-YA at $673 \mathrm{~K}$, (c) FC-00 at $873 \mathrm{~K}$ and (d) FC-5Y at $1073 \mathrm{~K}$.

\section{REFERENCES}

1) Y. Ikeda, M. Tosa, K. Yoshihara and K. Nii: ISIJ InI., 29 (1989), 966.

2) Y. Ikeda, H. Sumiyoshi and Y. Ishiwata: ISIJ Int., 35 (1995), 1109.

3) INCO Alloy Intern. Inc.: Product Handbook, Publication No. IAI-38, (1988), 27.

4) J. D. Whittenberger: Metall. Trans., 9A (1978), $10 \mathrm{I}$.
5) T. Okuda, S. S. Nomura, M. Nakanishi, M. Fujiwara and H. Takahashi: Proc.1st Japan Int. SAMPE Sym., Chiba Japan, 28, Dec., I (1989), 1616

6) H. S. Ubhi, T. A. Hughes and J. Nutting: Frontiers of High Temperature Materials, ed. by J. S. Benjamin, Inco MAP, New York, (1981), 79.

7) H. Tanaka, F. Abe, K. Yagi, E. Nishikawa and T. Sugita: CAMP-ISIJ, 8 (1995), No. 6, S366.

8) H. Read and H. Murakami: Appl. Surf. Sci., 94/95 (1996), 334 